\title{
THE NAMIBIAN BORDER WAR: AN APPRAISAL OF THE SOUTH AFRICAN STRATEGY
}

\author{
Dr Leopold Scholtz ${ }^{1}$ \\ Extraordinary Professor, Department of History, \\ Stellenbosch University
}

\section{Introduction}

From the sixties to the late eighties, the border war became a household term in South Africa. Hundreds of thousands of young white men were called up for military service, and many served in some or other capacity in Namibia - then South West Africa - often in the so-called operational area, often as combat troops. These young men were told that they were there to fight communism and that Swapo (the South West African People's Organisation), the enemy, had to be bested for peace and freedom to come to the southern African subcontinent.

Nevertheless, when the UN-supervised elections came after years of international wrangling, Swapo won handsomely, obtaining 57 per cent of the votes. The South African Government and South African Defence Force (SADF) was taken aback, because they really had believed that the anti-Swapo coalition would get a majority. ${ }^{2}$ The question therefore is: How was this possible? Did the South Africans, who developed a sophisticated strategy to counter-revolutionary guerrilla warfare and really were convinced that they had Swapo on the run, make mistakes they were not aware of? Did they disobey in practice the rules they supported in theory? It will be the purpose of this analysis to answer this question.

\section{Principles}

In order to do this, we will have to start with a short analysis of the accepted principles of revolutionary guerrilla warfare, as they developed during the 20th century.

\footnotetext{
${ }^{1}$ Dr. Leopold Scholtz is also Deputy Editor of Die Burger in Cape Town and a captain (infantry) in the Reserve Force of the SA Army.

${ }^{2}$ Cf. Hilton Hamann: Days of the Generals. The Untold Story of South Africa's Apartheidera Military Generals (Cape Town, Zebra, 2001), pp. 178-179; Brian Pottinger: The Imperial Presidency. P.W. Botha the First 10 Years (Johannesburg, Southern, 1988), p. 212.
} 
It is a political struggle: It is generally true of all wars that they are political in nature. The famous $19^{\text {th }}$-century Prussian military philosopher Carl von Clausewitz postulated the well-known dictum that war is a continuation of politics by other means. By this he meant that politics (or the political leaders) are the brains behind warfare, which essentially is the tool of a government in the pursuance of a political aim. War's "grammar, indeed, may be its own, but not its logic," he says. As a matter of fact, war without politics is "something pointless and devoid of sense". ${ }^{3}$

Obviously, the context of revolutionary war is somewhat different in the sense that it is not a struggle between two sovereign states, but between a government and a revolutionary movement which tries to overthrow it. However, this does not alter the basic truth of the Clausewitzian logic. This type of war, even more so than conventional war, is essentially political in nature.

However, the nature and intensity of the aim has a profound influence on the character of any specific war. "The smaller the penalty you demand from your opponent," Clausewitz says, "the less you can expect him to try to deny it to you." The opposite is also true, as "the more modest your own political aim, the less importance you attach to it and the less reluctantly you will abandon it if you must." ${ }^{4}$

These observations are important if we want to understand the revolutionary wars in Southern Africa. All the revolutionary movements in the region, from the MPLA in Angola, Frelimo in Mozambique, Zanu/Zapu in Rhodesia to the ANC in South Africa, wanted to overthrow the white-dominated minority governments in order to replace them with socialist states, representing the black majorities. However, although Swapo too wanted a socialist state, it had no interest in completely destroying apartheid South Africa, and in contrast to the ANC never presented its aims in that way. Thus, the war in Namibia, objectively speaking, never became a question of survival for the South Africans, although a Swapo take-over there, in the minds of some South Africans, would indeed increase the pressure on their core base. Nevertheless, they could afford to lose the war there without being destroyed totally, which made it easier for them in the end to hand over power on favourable terms.

Mao's 'three phases': Another fundamental point to understand about revolutionary guerrilla warfare is the basic three-phase model originated by Mao Zedong in the 1930's. Mao distinguished three phases in revolutionary guerrilla war. The first was when the guerrillas were still weak and the enemy strong; the second

\footnotetext{
${ }^{3}$ Carl von Clausewitz: On War, VIII/6B, ed. and translated by Michael Howard and Peter Paret (Princeton, Princeton University Press, 1976), p. 605.

${ }^{4}$ Ibid., I/1, p. 81.
} 
one of "strategic stalemate" and "mobile warfare"; and the third, during which conventional war takes place. ${ }^{5}$

This should not be regarded as an iron law, as the third phase may not be necessary at all. For instance, external and/or internal pressure may cause the antirevolutionary forces to abandon the fight before the onset of the third stage, as happened with the French in Algeria and Vietnam, the Americans in Vietnam, the Soviets in Afghanistan, the Portugese in their African colonies, the South Africans in Namibia, and the Rhodesians in their own country.

'Fish in the water': Without the support of the local population, no guerrilla force can ever hope for success. Mao stated that guerrilla warfare "must fail... if its political objectives do not coincide with the aspirations of the people and their sympathy, co-operation, and assistance cannot be gained... [b]ecause guerrilla warfare basically derives from the masses and is supported by them, it can neither exist nor flourish if it separates itself from their sympathies and co-operation."6

Mao also wrote: "Many people think it impossible for guerrillas to exist for long in the enemy's rear. Such a belief reveals lack of comprehension of the relationship that should exist between the people and the troops." Then came the famous slogan, illustrating the point beautifully: "The former may be likened to water; the latter to the fish who inhabit it. How may it be said that these two cannot exist together? It is only undisciplined troops who make the people their enemies and who, like the fish out of its native element cannot live."7

In his excellent study of the revolutionary wars against the Portuguese colonial regimes, "Kaas" van der Waals points out that "revolutionary war differs from conventional war because its centre of gravity is not to be found in the destruction of opposing armed forces and the occupation of territory, but rather in hijacking the socio-political system by obtaining control over the population." ${ }^{8}$ In other words, not the armed forces of the enemy are the primary target of the revolutionaries; rather, the population is seen as the centre of gravity, the fundamental goal.

Political work: This symbiosis between the revolutionaries and the people which Mao emphasised, does, of course, not fall from heaven. It entails hard, slogging propaganda and political work, day by day, week by week, month by month, to establish the revolutionary movement among the people, to win their trust

\footnotetext{
${ }^{5}$ Mao: "On Protracted War", Selected Military Writings, pp. 210-215; Mao: "Problems of Strategy in China's Revolutionary War", Selected Military Writings, pp. 113-115.

${ }^{6}$ Mao: "On Guerrilla Warfare", ch. 1, at eastofhateandfear.com/archives/tse_tung.html.

${ }^{7}$ Ibid., ch. 6, at eastofhateandfear.com/archives/tse_tung.html.

${ }^{8}$ WS van der Waals: Portugal's War in Angola 1961-1974 (Rivonia, Ashanti, 1993), pp. 263 264.
} 
and support. This applies especially to the first of Mao's three phases, when the revolutionaries are still weak.

For any revolutionary war, the foundations thus laid are of supreme importance. The legendary Vietnamese General Vo Nguyen Giap later wrote of this stage "that political activities were more important than military activities, and fighting less important than propaganda". 9

Revolutionary bases: One of the most important conditions for a succesful revolutionary guerrilla war is the establishment of liberated base areas. According to Mao Zedong, these are necessary for several reasons. Firstly, for rest and recuperation after arduous guerrilla operations in the enemy's rear, but there is also a political motive: "[W]e must form mass organisations, we must organise the workers, peasants, youth, women, children, merchants and professional people according to the degree of their political consciousness and fighting enthusiasm into the various mass organisations..." ${ }^{10}$ In other words, Mao's base areas became the places where an alternative state, with an alternative government, administration and ideology was set up.

Terrorism: This is not to say that the people's active support may be taken for granted. If propaganda and political mobilisation is not enough, terrorism has often been used as a tool to ensure at least the people's passive acceptance of the revolutionaries' presence and political agenda.

Brian Crozier distinguishes between two types of terrorism, disruptive and coercive. The first is aimed at the enemy; the second at the local population on whose aid the revolutionaries are dependent. ${ }^{11}$ For example, notwithstanding Mao's dictum about the fish and the water, he was not averse to using drastic methods to get the people in line. As was the case with Lenin, Mao explicitly endorsed the use of terror as indispensable to the communist cause. At first, it was only to be used against "class enemies", but this rapidly degenerated into a weapon against fellow Party members in Mao's power struggle against his rivals. ${ }^{12}$

Spread the war as wide as possible: One of the most obvious military principles is concentration of force. You have to concentrate your forces so that you have a mailed fist at the point you wish to attack. Or, conversely, you have to concentrate at the point the enemy is attacking.

\footnotetext{
${ }^{9}$ Vo Nguyen Giap: People's War, People's Army. The Viet Công's Insurrection Manual for Underdeveloped Countries (New York, Bantam, 1968), p. 68.

${ }^{10}$ Mao: "Problems of Strategy in Guerrilla War against Japan", Selected Military Writings, pp. 167-176.

${ }^{11}$ Brian Crozier: A Theory of Conflict (London, Hamish Hamilton, 1974), pp.127-128.

${ }^{12}$ Cf. Philip Short: Mao. A Life (London, Hodder and Stoughton, 1999), pp. 265-271.
} 
In guerrilla warfare, the exact opposite applies. You have to disperse your force as widely as possible, while concentrating only locally when you wish to attack an isolated enemy position or unit, and dispersing immediately when the fight is over. By dispersing your own forces, you force the anti-guerrilla powers to do the same. The government or occupying force must, for political reasons, be seen to occupy the whole country physically and be able to provide security everywhere. The problem is that they don't know where your next blow will fall, even if it amounts to nothing more than a pin-prick. With hundreds of pin-pricks that never end, chances are that you may force the enemy to over-extend himself. ${ }^{13}$

Arguably the most profound modern French strategic thinker, General André Beaufre, put the matter very concisely: "For guerrilla warfare it is a question of menacing the adversary over the largest possible area... Doing so, it obliges regular forces to disperse their means over an area exceeding their capability, while the guerrillas remain capable of acting wherever they choose." 14

Dispersal of effort: The principle of forcing the enemy to disperse his forces does not only apply to the physical level. It is also true of the political and psychological terrain. To see revolutionary warfare only or even primarily as a military process is to miss the point completely. The wise revolutionary will attack and isolate its enemy on every front possible, be it the economy, labour relations, the church, international politics, culture, the media, etc. Even negotiations will be viewed as part of the war. Making use of every possible network is central to the revolutionary strategy.

"To reach these networks, the $4 \mathrm{GW}\left[4^{\text {th }}\right.$ Generation Warfare] operational planner must seek various pathways for various messages," opines Thomas X. Hammes. "Traditional diplomatic channels, both official and unofficial, are still important but no longer the only pathway for communication and influence. Other networks rival the prominence of the official ones. The media are rapidly becoming a primary avenue." ${ }^{, 15}$ This means that the government or regime will have to fight on every front simultaneously, whereby its collective effort is dispersed as much as its armed forces.

\section{The South African doctrine}

Before we come to the war itself, we will have to look briefly at how the South Africans translated these principles into their own doctrine. To begin with,

${ }^{13}$ This factor also applied par excellence to the Anglo-Boer War. Cf. Leopold Scholtz: Why the Boers Lost the War (London, Macmillan, 2005), ch. 6; Leopold Scholtz: "Clausewitz, Mao Zedong en die Anglo-Boereoorlog", Joernaal vir Eietydse Geskiedenis, 25/2, Dec. 2000, pp. 264-265.

14 André Beaufre: Strategy for Tomorrow (Menlo Park, California, Stanford Research Institute, 1974), pp. 39-40. His italics.

${ }^{15}$ Thomas X. Hammes: The Sling and the Stone. On War in the 21st Century (St. Paul, Zenith, 2004), pp. 213-214. 
they studied the way the Portuguese and Rhodesians fought their wars closely and learnt many lessons, both about how to do things, but also about the mistakes made there. $^{16}$

Especially two writers exercised great influence, the American J.J. McCuen and Lieutenant-General Alan "Pop" Fraser, Chief of Joint Operations of the SADF in the sixties and a veteran of the British COIN campaign in Malaya in the fifties. ${ }^{17}$ McCuen proposed five strategic and four tactical principles when fighting revolutionary guerrillas. ${ }^{18}$ His tactical principles, which need concern us no more here, were, shortly, keeping the initiative, having good intelligence, maintaining mobility and achieving surprise. His strategic principles were the following:

- Having a clear political aim: In the light of the intense political nature of revolutionary warfare, McCuen places great emphasis on this aspect. Without it, neither the civilian administration of the government nor the military can properly deal with the evolving phases of the rebellion.

- Annihilation of the enemy and preservation of own forces: Obviously, the enemy forces will have to be destroyed, but not to the point of seriously weakening your own forces. The areas which have not yet be subverted, should be safeguarded and developed in order to prevent such subversion from happening. At the same time - and this proved to be very important to the South Africans - the internal and external political infrastructure of the rebels should be high on the agenda for destruction.

- Mobilisation of the masses: This principle rests directly on what Mao had said about the matter, that the active participation of the masses should be secured, especially as far as the so-called silent majority is concerned. In addition, the government should offer a vision which is more attractive than the one offered by the rebels. This should accommodate popular aspirations and eleminate genuine grievances.

- Get outside support: To get the political and moral support of neigbouring states is necessary to counter the external manoeuvres of the revolutionaries.

- Unity of effort: All means and instruments available should be effectively integrated into one consolidated effort. Government departments should not make ad hoc decisions which are not properly integrated into the central war effort, and this applies not only to military steps, but also those in the political, psychological, economic and organisational realms. This principle, when read together with the writings of Beaufre, was the

\footnotetext{
${ }^{16}$ John W. Turner: Continent Ablaze. The Insurgency Wars in Africa 1960 to the Present (Johannesburg, Jonathan Ball, 1998), p. 29; Francis Toase: "The South African Army: The Campaign in South West Africa/Namibia since 1966", in Ian F.W. Beckett and John Pimlott (eds.): Armed Forces \& Modern Counter-Insurgency (London, Croom Helm, 1985), p. 199.

${ }^{17}$ There was actually a third writer too, the French General André Beaufre, but his influence did not so much lay in the realm of COIN strategy.

${ }^{18}$ John J. McCuen: The Art of Counter-Revolutionary War (Harrisburg, Stackpole Books), pp. 30-44.
} 
foundation of the P.W. Botha government's much maligned Total Strategy.

At the same time, General Fraser, who was, perhaps apart from General Jannie Geldenhuys, the only senior South African military man who approached the phenomenon of revolutionary guerrilla warfare with a more or less intellectual frame of mind, formulated the following points in a paper entitled Lessons learnt from Past Revolutionary Wars as summarised by Geldenhuys, Chief of the SADF in the eighties (McCuen's influence is obvious): ${ }^{19}$

- A revolutionary war is a political war;

- The purpose of both sides in a revolutionary war is to win the support, endorsement, sympathy and active participation from the population;

- The government should win the political iniative over the insurgents by having a cause which is even more attractive that the one inspiring them;

- The danger of complacency (refusal to recognise the true situation) must be avoided before and during a revolution;

- There must be a high-quality intelligence organisation; and

- Bureaucratic delays in a revolutionary war is as dangerous as subversion itself.

The following words of Stephen Ellis is a very good summary of the South African general security strategy as it developed during the seventies and eighties (the quotation is, of course, about South Africa itself, but is perfectly applicable to the South African strategy in Namibia as well):

In the view of the securocrats, then, the aim of violence was less to destroy the enemy's armed forces than to win the support of the population by a mixture of political action, intimidation, propaganda and the symbolic manifestation of those socio-economic grievances which made South Africa fertile ground for revolutionaries. For the securocrats, most of whom were professional soldiers and policemen rather than politicians, the war was essentially a management in which the security and welfare functions of government had to be integrated for the overall purpose of preserving the life of the state. This is the ideology of sophisticated military rulers. They believed that it was above all the use of revolutionary violence and propaganda by the ANC and its allies which accounted for the ANC's success in winning support from what they saw as an essentially manipulable black population, as part of what became, after the late 1970s, a classical revolutionary strategy. ${ }^{20}$

\footnotetext{
${ }^{19}$ Jannie Geldenhuys: Dié wat wen. 'n Generaal se storie uit 'n era van oorlog en vrede (Kaapstad, Van Schaik, 1993), p. 64. In 1986 Fraser's study was translated into Afrikaans and circulated to senior officials in South Africa. Cf. Stephen Ellis: "The Historical Significance of South Africa's Third Force", Journal of Southern African Studies, 24/2, June 1998, p. 275.

${ }^{20}$ Ellis: "The Historical Significance of South Africa's Third Force", Journal of Southern African Studies, 24/2, June 1998, p. 265.
} 
It is clear that the South Africans, in theory, had developed a very sophisticated approach to Swapo's onslaught which embodied a good understanding of revolutionary guerrilla warfare principles. The question is to what extent they practised what they preached.

\section{The beginnings}

The war is generally thought to have started on 28 August, 1966 when a force of 130 men - mostly policemen under the command of Commandant (Lieutenant-Colonel) Jan Breytenbach and 9 of his paratroopers from 1 Para Bn swooped down on the secret Swapo base of Ongulumbashe in Ovambo with 35 Alouette III helicopters. This was early days, and the tactical inexperience of the South Africans showed in the fact that only two guerrillas were killed and nine taken prisoner. ${ }^{21}$ Of the rest, according to Willem Steenkamp, 45 were eventually caught. ${ }^{22}$

The start of Swapo's armed struggle to drive out the - as they saw it - South African colonialists, was a direct result of decades' humiliation at the hands of whites, just as their equivalents' struggle in South Africa flowed from the white government's discrimination and violence towards blacks. As Pastor Siegfried Groth, who in later years became one of Swapo's greatest critics, wrote of the sixties:

Namibian men and women were no longer prepared to accept oppression and humiliation. The prisons in Ovamboland were full to overflowing. Hundreds of people, including women, were whipped in public. The victims had to undress and were then brutally beaten on their buttocks with a six-foot long palm-tree cane. Anyone who tried to resist the South African dictatorship received electric shock treatment and was imprisoned without trial for months or even years. ${ }^{23}$

In 1959, a public protest in Windhoek's Old Location against a forced population removal to Katutura led to a police shooting and the death of 11 people, while 54 were wounded. The South African authorities also practised the apartheid policy in the territory through social segregation at grassroots leven and the duplication of its homelands policy. ${ }^{24}$ All of this is important in the present context, as it partly explains why Swapo, even though it proved to be a very imperfect

${ }^{21}$ Peter Stiff: The Silent War. South African Recce Operations 1969-1994 (Alberton, Galago, 1999), pp. 36-37.

${ }^{22}$ Willem Steenkamp: South Africa's Border War 1966-1989 (Gibraltar, Ashanti, 1989), p. 22.

${ }^{23}$ Siegfried Groth: Namibia - the Wall of Silence. The Dark Days of the Liberation Struggle (Wuppertal, Hammer, 1995), p. 33.

${ }^{24}$ Peter H. Katjavivi: A History of Resistance in Namibia (London, James Curry, 1988), pp. 47-49 and 72-73. 
liberation movement, succeeded in retaining such loyalty from so many black Namibians for so long.

The first years of the war were very low-key. After having been decimated at Ongulumbashe, Swapo did not enter Ovamboland again for some years. Instead, the Caprivi strip, being relatively accessible from Zambia, for the time being became the main battleground. Swapo had moved its headquarters to Lusaka in 1962, and Zambia became the main staging ground for the insurgency. ${ }^{25}$ This was favourable to South Africa, as the war's centre of gravity proved not to be in Caprivi, but Ovamboland further west, where 46 per cent of the Namibian population lived. Ovamboland was also the area where Swapo, most of their leaders being Ovambos, would have the best chance of gaining the support and trust of the locals. The Caprivians were loyal to Canu (Caprivi African National Union), and their support hinged on the precarious alliance between Swapo and Canu holding up.

In the meantime, the SADF looked on in growing frustration how their role in the fight at Ongulumbashe were not only being denied in public, but how the SA Police was given the task of nipping the uprising by these few uppity blacks - as it was seen - in the bud. The SADF was also denied the chance of getting muchneeded combat experience in Rhodesia, where the Police took the honours of helping the Rhodesians fight their war. ${ }^{26}$ Moreover, most of the policemen employed in patrolling the operational area were riot policemen whose effectivity was at best dubious. According to Annette Seegers, their approach "seems to have been searchand-capture, consistent with policing that aims at a criminal trial". Patrols and hearts-and-mind activities played a secondary role. The riot policemen were pulled out in 1968, after which the SAP started a COIN training course in Pretoria. Until 1972 only whites were employed, after which the experience of the Rhodesians convinced the SAP to bring in black policemen as well. ${ }^{27}$

But even good policemen aren't necessarily trained to be good soldiers. And so, when several countrywide strikes broke out in Namibia in 1972 and the police found it impossible to cope with internal security as well as the insurgency, the government at last decided to turn the war over to the military. In spite of its lack of combat experience, the SADF was better placed to do the job. It had more man- and firepower, and had already started training some of its soldiers in COIN operations in $1960 .{ }^{28}$ Some of their senior ranks, like General Fraser, had also given considerable theoretical thought to how to fight a counter-insurgency war.

${ }^{25}$ Susan Brown: "Diplomacy by Other Means. Swapo's Liberation War", in Colin Leys and John S. Saul: Namibia's Liberation Struggle. The Two-Edged Sword (London, James Currey, 1995), p. 21.

${ }^{26}$ Cf. Hamann: Days of the Generals, p. 9.

${ }^{27}$ Annette Seegers: The Military in the Making of Modern South Africa (London, Tauris, 1996), pp. 137-138; Toase: "The South African Army: The Campaign in South West Africa/Namibia since 1966", in Beckett and Pimlott (eds.): Armed Forces \& Modern Counter-Insurgency, pp. 202-203.

${ }^{28}$ Cf. Geldenhuys: Dié wat wen, p. 64. 
The military finally took over responsibility for the war on 1 April 1974. Just in time, because just more than three weeks later, on 24 April, a coup d'etat toppled the Portuguese fascist dictatorship, and soon afterwards the new government announced that it would pull out of its African empire in Mozambique, Angola and Guinea-Bissau.

\section{South Africa loses the war}

The strategic consequences of the Portuguese military forces leaving Angola were tremendous. No longer could the South Africans count on them to prevent Swapo from infiltrating Namibia through Angola. In his memoirs, Swapo leader and later Namibian president Sam Nujoma wrote perceptively: "Our geographical isolation was over. It was as if a locked door had suddenly swung open. I realized instantly that the struggle was in a new phase... For us [it] meant that... we could at last make direct attacks across our northern frontier and send in our forces and weapons on a large scale." To reflect the new reality, Swapo's headquarters was presently moved again from Lusaka to Luanda. ${ }^{29}$

This is not the place for an analysis of Operation Savannah, the South African invasion of Angola in support of the pro-Western FNLA and Unita movements against the Marxist MPLA. ${ }^{30}$ Suffice it to say that South Africa intervened after having been requested to do so by the governments of the United States, Zambia, the Ivory Coast and by Unita. Four South African combat groups marched rapidly hundreds of kilometres northwards in a remarkable lightning campaign, before international politics scuttled it. Firstly, Cuba sent several thousands soldiers and heavy weapons to Angola in order to bolster the MPLA, which took control of the capital, Luanda, and esconced itself as government of the newly independent Angola. Then the US withdrew its support, while the Organisation of African Unity decided to back the MPLA as well. With this, the international backing of the South African intervention collapsed and the government in Pretoria felt that it had no option but to withdraw, a process that was completed early in $1976 .^{31}$

\footnotetext{
${ }^{29}$ Sam Nujoma: Where Others Wavered. The Autobiography of Sam Nujoma (London, Panaf, 2001), pp. 228-229, 234.

${ }^{30}$ The fullest description is given by F.J. du Toit Spies: Angola. Operasie Savannah (Pretoria, SA Weermag Direktoraat Openbare Betrekkinge, 1989), while Sophia du Preez: Avontuur in Angola. Die Verhaal van Suid-Afrika se Soldate in Angola 1975-1976 (Pretoria, Van Schaik, 1989), presents a more popular and readable account (in Afrikaans). The Cuban sources have recently been unlocked by Piero Gleijeses: Conflicting Missions. Havana, Washington, Pretoria (Alberton, Galago, 2003).

${ }^{31}$ This has never been the subject of a military historical debate. Cf. Colonel Jan Breytenbach: The Buffalo Soldiers. The Story of South Africa's 32-Battalion 1975-1993 (Alberton, Galago, 2002), pp. 123-127 for a very thought-provoking analysis of the operation.
} 
Operation Savannah did have one lasting advantage for South Africa. The SADF gained a new ally, namely Jonas Savimbi's Unita, which was previously friendly to Swapo. ${ }^{32}$ But the advantages would not make themselves felt for several years. In the meantime, Swapo moved swiftly to exploit the new possibilities. Within a few months of Portuguese control in southern Angola collapsing, the area was swarming with Swapo bands, and from October 1975, for the first time since 1966, Swapo made its presence felt in Ovamboland with an invasion of over 500 trained guerrillas. ${ }^{33}$ Within a reasonably short time, the South African security forces were in really big trouble.

The consequences of the Angolan debacle was very negative for South Africa. Firstly, the combination of the harsh treatment of blacks under the apartheid system and the hope for liberation furnished by what was perceived to be a South African beating at the hands of the Cubans and the MPLA, brought about a veritable exodus of young Namibians across the border to Swapo. ${ }^{34}$ According to SADF intelligence, Swapo's military strength increased from about 400 trained guerrillas in 1974 to approximately 2000 in $1976 .^{35}$

Swapo thus succeeded in breaking out of the relatively strategically unimportant territory of Caprivi. By being able to utilise southern Angola, they were in a position to infiltrate large bands of guerrillas into Kavango as well as the geographical centre of gravity, Ovamboland - thereby stretching the operational area to a great extent and threatening to overstretch the security forces. But Swapo was even more ambitious than this: As the chief of staff of Plan (The People's Liberation Army of Namibia, Swapo's army), David Namholo, related to Susan Brown, their strategy "was changed to cross into farming areas, going to urban areas rather than just being in the north or in Caprivi..." 36 And indeed, for a time sabotage and bomb explosions were reported in Windhoek, Gobabis, Swakopmund, etc. ${ }^{37}$

In order to combat Swapo, the SADF relied mainly on white conscripts and reservists, often from the cities, who proved to be unsuitable. Being a fair sample of the white community with their paternalistic and even racist attitudes at the time, they were at a disadvantage when dealing with tribal blacks of whom they knew nothing and understood even less. This certainly did not help in getting the loyalty

\footnotetext{
${ }^{32}$ Hammann: Days of the Generals, p. 69.

${ }^{33}$ Brown: "Diplomacy by Other Means", in Leys and Saul: Namibia's Liberation Struggle, p. 21; Helmoed-Römer Heitman: South African Armed Forces (Cape Town, Buffalo, 1990), p. 146.

${ }^{34}$ Brown: "Diplomacy by Other Means", in Leys and Saul: Namibia's Liberation Struggle, p. 23; Nujoma: Where Others Wavered, p. 229; Groth: Namibia - the Wall of Silence, p. 33.

${ }^{35}$ Heitman: South African Armed Forces, p. 146.

${ }^{36}$ Brown: "Diplomacy by Other Means", in Leys and Saul: Namibia's Liberation Struggle, p. 24.

${ }^{37}$ Cf. Peter Stiff: The Covert War. Koevoet Operations Namibia 1979-1989 (Alberton, Galago, 2004), pp. 21-22; Eugène de Kock: A Long Night's Damage. Working for the Apartheid State (Saxonwold, Contra, 1998), p. 66.
} 
and support of the locals, which meant that the security forces got little or no intelligence, and when they got it, it was mostly too old to be useful. ${ }^{38}$ Eugène de Kock, who later became notorious as a police assassin in service of the apartheid government, was at this stage a police station commander in Ruacana. His observation was that Swapo "seemed to be doing what it liked". In his memoirs, he writes that Swapo "was ahead of us in most respects". The main reason was that "our troops were not bush-savvy. We took a boy who had just matriculated, gave him a gun, two to three months of basic training - and then threw him in the middle of a country that he did not know, people he did not understand and an enemy that he had never seen. No wonder he did not do very well. ${ }^{, 39}$ Indeed, how could you expect city boys to track and find guerrillas who grew up in the area and knew every bush-craft trick in the book when they did not want to be found?

Not only that, South African tactics also were clumsy and unwieldy. Colonel Jan Breytenbach relates with more than just a touch of sarcasm how the then Major-General Constand Viljoen, General Officer Commanding (GOC) South West Africa Command, launched a big sweeping operation to clear out Swapo elements that had infiltrated into northern Ovamboland in the wake of South Africa's retreat from Angola. They caught exactly nothing in their nets. Masses of infantry were called up from South Africa. Huge convoys headed north. Supply bases, bursting at the seams, were set up in the operational area to provide everything from hot showers to ample issues of daily ration packs. Battalions of infantry were moved backwards and forwards through the bush in long sweep lines south of the cutline [border], like General Kitchener's troops during the Anglo-Boer War. It was the biggest deployment of South African troops since World War II. But this huge force did not get a single kill. ${ }^{40}$

Eugène de Kock also observed that the security forces had a disdain for Swapo at the time because the guerrillas never stood and fought:

The fact that Swapo soldiers were seldom seen, and resisted getting into setpiece engagements, reinforced the view that they were ineffectual and merely a nuisance. This was not so. Swapo groups - large ones at that - moved freely around Ovamboland. But, because they could not be found, they did not exist for the security forces. ${ }^{41}$

\footnotetext{
${ }^{38}$ Cf. Breytenbach: The Buffalo Soldiers, p. 200.

${ }^{39}$ De Kock: A Long Night's Damage, p. 65. Cf also Brigadier-General McGill Alexander's opinion in his MA thesis, "The Cassinga Raid" (Unpublished MA thesis, Unisa, July 2003), p. 40.

${ }^{40}$ Breytenbach: The Buffalo Soldiers, p. 149.

${ }^{41}$ De Kock: A Long Night's Damage, p. 66. This was Operation Cobra, launched in May 1976. Cf. Toase: "The South African Army: The Campaign in South West Africa/Namibia since 1966", in Beckett and Pimlott (eds.): Armed Forces \& Modern Counter-Insurgency, p. 210 .
} 
Recalling that era, a senior Swapo commander told Susan Brown years later that "the enemy had no influence among the masses... During that time, even the SADF were under-trained. They were not specialised in guerrilla tactics. That is why they found it difficult to track down guerrillas during that time; they were not in a position to move in the areas where we used to operate and they got demoralised. At that time we had the upper hand." ${ }^{2}$ Indeed, reviewing the situation at the end of 1977, SADF intelligence concluded that Swapo's standard of training had improved significantly because of the training they had received from Cuban instructors. ${ }^{43}$

Moreover, Swapo's freedom of movement meant that they could assassinate local pro-South African headmen and officials almost at will pour encourager les autres. One of the first was the "chief minister" of Ovamboland, Filemon Elifas. ${ }^{44}$ As we have seen in the theoretical introduction, selective terrorism can be a strong incentive for the locals to support the insurgents.

Truth is, by the end of 1977 the SADF was losing the war in Nambia. In the period 1966-'77, 363 Swapo guerrillas were killed in action compared with 88 security force members ${ }^{45}$ - a "kill ratio" of only 4,1 to 1 , hopelessly inadequate in a guerrilla conflict. All of this was, however, about to change. In January 1976 Major-General Jannie Geldenhuys was appointed GOC South West Africa Command. During his command period of five years, a series of measures were took which completely turned the war around.

\section{The turn-around: security strategy}

On the security strategic level South Africa in the early seventies was really in an unwinnable situation. Internally as well as internationally it was regarded as an illegal colonial occupier of the territory. Officially, Namibia was administrated "in the spirit" of the old League of Nations mandate of 1919 (which was revoked by the International Court of Justice in 1971), but in practice it was simply run as a fifth province of the Republic. In fact, Pretoria was intent on applying the policy of grand apartheid, with self-governing and eventually independent homelands for the different black ethnic groups. Petty apartheid - segregation on grassroots level - was applied assiduously by an army of officials and policemen. This, as we have seen, provided the main cause of dissent, giving rise to Swapo's insurgency.

However, Pretoria responded with a pragmatism that was, at the time, quite surprising. Instead of the usual semi-theological arguments of apartheid being a naturally-ordained way of ordering human relations, instead of a blanket refusal to

\footnotetext{
${ }^{42}$ Brown: "Diplomacy by Other Means", in Leys and Saul: Namibia's Liberation Struggle, p. 27.

${ }^{43}$ Steenkamp: SA's Border War, p. 71.

${ }^{44}$ Brown: "Diplomacy by Other Means", in Leys and Saul: Namibia's Liberation Struggle, p. 25.

${ }^{45}$ Steenkamp: SA's Border War, p. 71.
} 
give up the territory, the government reacted flexibly, albeit slowly. In 1973 Prime Minister John Vorster declared that the Namibian population would have to decide their own future, thereby implicitly accepting that the territory could become independent. Four years later, a conference was convened at the Windhoek Turnhalle to enable the Namibians to decide on the political structures to govern them, but Swapo viewed this as a sham and boycotted the process. Progressively, all apartheid laws were repealed - a rather adventurous process, seeing that it was still unthinkable back in the Republic to bring about more than just cosmetic changes to apartheid. $^{46}$

It is also important to note that, in contrast to South Africa itself (where the ANC and other liberation movements remained proscribed), in Namibia Swapo was permitted to act as a legitimate political party. An anonymous South African official explained to an American military visitor that this was to "keep it out in the open, and keep the faint-hearted from going to Angola". 47

In the military field, the changes were reflected in an ever increasing number of blacks fighting for the South African administration, $32 \mathrm{Bn}$ (consisting of exFNLA fighters) being the first unit allowing blacks to join the previously lily-white SADF. This was followed by $31 \mathrm{Bn}$ (Bushmen), $101 \mathrm{Bn}$ (Ovambos), $201 \mathrm{Bn}$ (East Caprivi), 202 Bn (Okavango), 203 Bn (West Caprivi), and 911 Bn (ethnically mixed). Especially 32 and $101 \mathrm{Bn}$ were much more than ordinary infantry battalions, growing into what really amounted to motorised infantry brigades. Many blacks also joined the Police COIN unit Koevoet. With the exception of 32 Bn (SADF) and Koevoet (SAP), these all became part of the South West Africa Territorial Force (SWATF), an indigenous Namibian force under South African command which, during the eighties, supplied about 70 per cent of the military manpower in the territory, about 30000 men. More than 90 per cent of these had black, yellow or brown skins. $^{48}$

This did not mean that the South African government was content on handing Namibia over to Swapo. The South Africans viewed the war against Swapo as being a struggle against communism, and this explained their whole posture. As Minister of Foreign Affairs Pik Botha explained to dr. Chester Crocker, US Assistant State Secretary for Africa, in a face-to-face meeting in 1981, the South African government "thought it was important to U.S. to stop Soviet gains... Swapo's people are indoctrinated in Marxism every day... SAG's [South African Government] bottom line is no Moscow flag in Windhoek." ${ }^{49}$ His colleague for Defence, General Magnus Malan, was even more forthright. According to the US

\footnotetext{
${ }^{46}$ For a negative Swapo view of these developments, see Katjavivi: A History of Resistance in Namibia, pp. 84-103.

${ }^{47}$ Major Robert C. Owen: "Counterrevolution in Namibia", Aerospace Power Journal, Winter 1987-88, at www.airpower.maxwell.af.mil/airchronicled/apj87/owen.html.

${ }^{48}$ Geldenhuys: Dié wat wen, p. 77.

${ }^{49}$ Richard Leonard: South Africa at War. White Power and the Crisis in Southern Africa (Craighall, AD Donker, 1983), p. 251. My italics.
} 
minutes, "Malan flatly declared that the SAG can't accept prospects of a Swapo victory which brings Soviet/Cuban forces to Walvis Bay. This would result from any election which left Swapo in a dominant position. Therefore a Swapo victory would be unacceptable in the context of a Westminister-type political system. Namibia needs a federal system. SAG does not rule out an internationally acceptable settlement, but could not live with a Swapo victory that left Swapo unchecked power." 50 In other words, the abolition of apartheid - yes; an international settlement - yes; elections with universal suffrage - yes; but a Swapo victory - no! And so, on a security strategic level, the war became an attempt to win enough time to create the conditions in which Swapo would lose an election. ${ }^{51}$

Indeed, Pretoria did not have to look far for indications of Swapo's Marxist and dictatorial inclinations. In the aftermath of thousands of young, mostly idealistic Namibians flocking to Swapo's banners in Zambia and Angola, grassroots pressure built up to make the leadership accountable to the rank and file. This was not appreciated by either Sam Nujoma or his top lieutenants. Njoma convinced President Kenneth Kaunda of Zambia to order the Zambian Army to arrest the dissident leadership and keep them incommunicado in a prison in Lusaka. When the news leaked out and a writ of habeas corpus was issued by the court to produce the arrested, they were simply flown out to Dar es Salaam where several remained incarcerated for several years. Dissident thinking within Swapo was brutally suppressed. Inside Namibia, Swapo also took steps to ensure the neutralisation of possible dissidents. Many others were detained and cruelly tortured. ${ }^{52}$

Under heavy pressure Swapo held a congress in July and August, 1976 in Nampundwe, Zambia, where it adopted a new party constitution. But instead of making the party more open, democratic and accountable as the dissidents had demanded, it transformed Swapo into an orthodox Marxist-Leninist vanguard party. In the constitution, Swapo pledged to combat all forms of ethnic orientation and racism and to "unite all Namibian people, particularly the working class, the peasantry and progressive intellectuals into a vanguard party capable of safeguarding national independence and of building a classless, non-exploitative society based on the ideals and principles of scientific socialism." 53

\footnotetext{
${ }^{50}$ Ibid., p. 250.

${ }^{51}$ In 1978, part of P.W. Botha's reasoning for unleashing Operation Reindeer on Swapo, was: "Die Swapo-mag moes gebreek word voordat verkiesing gehou word." Cf. Dirk and Johanna de Villiers: PW (Kaapstad, Tafelberg, 1984), p. 341. Cf. also Geldenhuys: Dié wat wen, p. 49.

${ }^{52}$ Cf. Shipanga: In Search of Freedom, ch. 23-31; Lauren Dobell: Swapo's Struggle for Nambia, 1960-1991: War by Other Means (Basel, Schlettwein, 1998), pp. 47-51; Groth: Namibia - the Wall of Silence, pp. 55-66; John S. Saul and Colin Leys: "SWAPO. The Politics of Exile", in Leys and Saul: Namibia's Liberation Struggle, pp. 48-53; Colin Leys and John S. Saul: "Liberation without Democracy? The Swapo Crisis of 1976", Journal of Southern African Studies, 20/1, March 1994, pp. 123-147. For a Swapo view of the crisis, see Katjavivi: A History of Resistance in Namibia, pp. 105-108.

${ }^{53}$ Swapo: "Political Programme of the South West Africa People's Organization", adopted by the meeting of the Central Committee, Lusaka, July 28 - 1 August 1976, p. 6.
} 
Some observers, while conceding the "Stalinist register" or the "textbook example of Soviet-style phraseology", seek to portray it as merely opportunistic to gain the support of young Namibians and of the Soviet-bloc weapons suppliers. ${ }^{54}$ But why Swapo cannot simply be taken at its word, is not clear. After all, most African liberation movements, including the MPLA, PAIGC, Frelimo and the ANC, were at this stage either avowed Marxist-Leninist organisations or dominated by communists. ${ }^{55}$ There seems to be no reason to assume that the Swapo leadership did not mean what they said. After all, only a few months later, Sam Nujoma let the cat out of the bag when he said quite openly in an interview with SABC-TV in answer to a question whether Swapo would not be "left out in the cold" if a non-Swapo government took power on independence: "The question of black majority rule is out. We are not fighting even for majority rule. We are fighting to seize power in Namibia, for the benefit of the Namibian people. We are revolutionaries. We are not counter-revolutionaries." 56

Swapo's own political propaganda from the time reinforces the point. "Comrade Lumumba", reportedly the nom de guerre of "Plan's chief political commissar", wrote in 1986 in Swapo's propaganda publication The Combatant that political education among the masses "should be of class character, be based on the irreconcilable hatred against class enemies, capitalist and imperialist..." It should "strengthen the class position of our combatants in the interests of the toiling and exploited, but fighting people of Namibia".57 This is nothing if not orthodox Marxism-Leninism.

All of this meant that apartheid, race discrimination and colonial domination diminished as casus belli. What remained, was Swapo's avowed aspiration to convert Namibia into a Marxist one-party state, thereby enabling Pretoria, ironically enough, to present the conflict in the rather more respectable cloak of communist dictatorship versus liberal multiparty democracy. And that, we may surmise, weakened Swapo and strengthened Pretoria to some extent.

\section{The turn-around: military strategy}

Like the British army, the SADF traditionally looked down on an intellectual approach to war. This is illustrated by the fact that the Military Academy in

\footnotetext{
${ }^{54}$ Cf. Dobell: Swapo's Struggle for Nambia, p. 58; Saul and Leys: "SWAPO. The Politics of Exile", in Leys and Saul: Namibia's Liberation Struggle, p. 52; Denis Herbstein and John Evenson: The Devils are among us. The War for Namibia (London, Zed Books, 1989), pp. 47-49; Groth: Namibia: The Wall of Silence, pp. 131, 135 and 152. Cf. also Katjavivi: A History of Resistance in Namibia, p. 109.

${ }^{55}$ Cf. Leopold and Ingrid Scholtz: "Die ontstaan en ontwikkeling van die SAKP se tweefaserevolusiemodel" (two parts, as yet unpublished but accepted by the Tydskrif vir Geesteswetenskappe).

${ }^{56}$ Steenkamp: SA Border War, p. 74.

${ }^{57}$ Herbstein and Evenson: The Devils are among us, p. 41.
} 
Saldanha only instituted a course in military strategy in 1991, while military history has never really taken the necessary central position in providing officers with an intellectual understanding of what their profession entailed. It seems that the SADF preferred action above thinking - as if there was no need to understand what you were doing, and in doing so also understand how to do whatever you were doing. Quite a lot of the mistakes made during the course of the war was directly attributable to this unfortunate lacune. ${ }^{58}$

One general officer who, at least in hindsight, seems to have overcome this wide-spread disdain for knowledge and understanding, was General Jannie Geldenhuys. If one can accept his memoirs as an accurate mirror of what happened, he and his staff during the late seventies apparently really set their minds to how to root out the Swapo insurgency, keeping close to the dictums of McCuen and Fraser. ${ }^{59}$ Interpreting what he wrote there and going beyond, let us look at how the South Africans tackled the problem.

The basic strategic task was to prevent the conflict from developing beyond Mao's first phase to open mobile warfare, or even the final conventional phase. But how? The operative word here seems initiative. ${ }^{60}$

Internally, the security forces needed to wrest the initiative from the insurgents by forcing them into fights on the former's terms. As the security forces were much better equipped - and, as the eighties approached, also better trained than the Swapo guerrillas, ${ }^{61}$ such firefights would mostly end in the defeat of the insurgents. The SADF relied more and more on black and white professionals and less and less on the white conscripts and reservists who were clearly not up to the job.

By the end of the seventies, the Rhodesian "fire-force" system was taken over, adapted and perfected. Troops being utilised for defensive tasks, such as escorting vehicle convoys, guard duties, etc., were minimised to free up men for offensive tasks. ${ }^{62}$ Typically, the operational area would be patrolled aggressively and continuously, on foot, on horse, on motor cycles with muffled engines and on mine-resistant infantry vehicles such as Buffels, Casspirs (Koevoet and $101 \mathrm{Bn}$ ) and, at times, even Ratel IFV's or Panhard 90 armoured cars. They would invariably have expert trackers with them, often from $102 \mathrm{Bn}$ (Bushmen), although Koevoet preferred native Ovambos. When chancing on an enemy band's tracks, or when

${ }^{58}$ Cf. Seegers: The Military in the Making of Modern South Africa, p. 191; G.E. Visser: "Militêre professionalisme en die onderrig van Krygsgeskiedenis in die Suid-Afrikaanse Nasionale Weermag: 'n historiese perspektief', Scientia Militaria, 27/2, 1997, pp. 15-36; Leopold Scholtz: "Cuito Cuanavale: Wie het regtig gewen?", Scientia Militaria, 28/1, 1998, pp. 16-61.

${ }^{59}$ Cf. Geldenhuys: Dié wat wen, pp. 62-79.

${ }^{60}$ Ibid., pp. 67-73.

${ }^{61}$ Steenkamp: SA's Border War, p. 190.

${ }^{62}$ Geldenhuys: Dié wat wen, p. 69. 
receiving information from the locals about a Swapo unit in the vicinity, the news would be radioed to the nearest HQ. There a "Romeo Mike" (the Afrikaans term was reaksiemag or reaction force) team would be on alert. Often the RM would be paratroopers, flown in on Puma helicopters, with air support from specially converted Alouette III helicopters equipped with $20 \mathrm{~mm}$ cannon. These mostly proved devastating in firefights. Sometimes, a C-47 Dakota with parachute-equipped troops or a Dakota gunship, similar to the American "Puff the Magic Dragon" used in Vietnam, would also be used. In the case of Koevoet and $101 \mathrm{Bn}$, the RM would more often than not consist of ground troops, rushing to the battle zone in their Casspir vehicles. Although the insurgents would sometimes really astound the pursuing troops with phenomenal feats of physical endurance and excellent bushcraft techniques like anti-tracking or hiding themselves, often the contact would result in some or most of the insurgents being killed or wounded. Especially Koevoet, and to a somewhat lesser extent $101 \mathrm{Bn}$, became highly feared killing machines, achieving the highest "kill ratio" of all units in the war. ${ }^{63}$

With these methods, according to General Geldenhuys, the number of combat contacts with insurgents doubled in 1979 compared to the previous year. Of those contacts 85 per cent were initiated by the security forces, illustrating their ability to dominate the operational area militarily. ${ }^{64}$

Externally, the SADF decided not to wait for the insurgents to come to Namibia, do their mischief there and then try to kill or capture them, but to take the war to their bases in Angola and prevent them from coming to Namibia in the first place. In a military appreciation of the situation in Namibia, dated 1 April 1978, the SADF Chief of Staff Operations pointed out that Swapo's actions had notably improved the previous year, mainly because of the movement having many bases just across the border in Angola. In contrast, because the SADF was not allowed to cross the border in a big way, it was forced to react to Swapo, while Swapo retained the initiative. ${ }^{65}$

Actually, cross-border operations against Swapo had already started clandestinely soon after the SADF pulled out of Angola in the wake of Operation Savannah. Under the inspired but unorthodox leadership of Colonel Jan Breytenbach $32 \mathrm{Bn}$, consisting largely of black Angolans, struck repeatedly over the border and harassed Swapo in places where it deemed itself safe. It was his intention, Breytenbach wrote, "to turn the southern Angolan bush into a menacing, hostile environment for Swapo." In short, he wanted to "out-guerrilla the guerrillas", 66

${ }^{63}$ Cf. Al J. Venter (ed.): The Chopper Boys. Helicopter Warfare in Africa (Gibraltar, Ashanti, 1994), pp. 127-168; John W. Turner: Continent Ablaze. The Insurgency Wars in Africa 1960 to the Present (Johannesburg, Jonathan Ball, 1998), pp. 34-55.

${ }^{64}$ Geldenhuys: Dié wat wen, p. 87.

${ }^{65}$ Alexander: "The Cassinga Raid", p. 38.

${ }^{66}$ Breytenbach: The Buffalo Soldiers, p. 179. 
However, the first sizable external operation, Operation Reindeer, took place in April 1978, when a understrength composite parachute battalion was dropped over Cassinga, a large Swapo administrative, supply and training base about $300 \mathrm{~km}$ inside Angola, which was completely destroyed. This gave rise to a hysteric furore, with Swapo alleging that the approximately 700-1000 killed were all innocent and defenceless women and children refugees on the run from the South African racists. However, the newest research by a professional SANDF paratrooper General has shown that, although there were indeed some women and children refugees at the base, by far the majority were Swapo cadres. ${ }^{67}$ At the same time, another Swapo base at Chetequera, much nearer to the Namibian border, was also attacked and wiped out. ${ }^{68}$

But this was not the turning point. In spite of Swapo losing up to a third of its military strength at Cassinga and its war effort being hugely disrupted, this success in contradiction to all military principles - was not followed up, and within six months everything was back to where they were before Reindeer. ${ }^{69}$ Sam Nujoma writes that Swapo's strategy at this time was "to carry out military offensives on all these fronts [eastern Caprivi, Kavango, eastern and western Ovamboland and the Kaokoveld] at the same time, to confuse and overstretch the enemy's military power...."70

It was not to be. In the years to come, until 1984, Swapo was kept on the ropes with several successive operations, mostly with great success, at times less so. Operations Sceptic and Klipkop (1980), Protea and Daisy (1981), Super and Meebos (1982) and Askari (1983-'84) were, perhaps, the most well known, but there were also several smaller ones.

There can be no doubt that, taken as a whole, these cross-border operations, the regular ritual international condemnations notwithstanding, were hugely successful in breaking the back of the Swapo insurgency. As Susan Brown - not particularly friendly towards the apartheid government - put it perceptively:

Swapo's ability to strike at will into the Ovambo area of Namibia now began to diminish rapidly. Plan combatants, previously based within a few kilometres of the Namibian border, were forced hundreds of kilometres back into the Angolan hinterland. The Plan headquarters and regional command points came under constant air and ground attack. Forward command posts from which guerrillas operated into Namibia became increasingly insecure if close to the border, with their lines of supply disrupted. When Swapo could no longer establish bases close to the border, this imposed on combatants the

\footnotetext{
${ }^{67}$ Alexander: "The Cassinga Raid", p. 170.

${ }^{68}$ Willem Steenkamp: Borderstrike! (Durban, Butterworths, 1983), pp. 104-134.

${ }^{69}$ Cf. Breytenbach: The Buffalo Soldiers, p. 210; Alexander: "The Cassinga Raid", pp. 176178.

${ }^{70}$ Nujoma: Where Others Wavered, p. 316.
} 
need to carry land-mines, mortars, automatic rifles, medical equipment and so on hundreds of kilometres on their backs before they even entered Namibia, let alone crossed into white farming areas. This long trek south was impossible without water, so Plan operations became restricted to the rainy season between November and March... This cut into the time combatants were able to stay in Namibia. This crucially affected their ability to conduct political work among the local population. After 1982, the politicising role of guerrillas who move continually and easily among the people of Ovamboland, often in civilian clothes, able to communicate and convince, began to wane. The role of combatants was increasingly forced into an exclusively military mould. ${ }^{71}$

The culmination of this series of cross-border operations was Operation Askari, which started in December 1983 and lasted into 1984. The concomitant clashes with Fapla, under whose wings Plan had seeked protection against the SADF invaders, moved the MPLA government to seek accommodation with the South Africans, and a half-hearted joint effort was started in terms of the Lusaka Accord to stop the fighting and keep Swapo out of the border area. The conclusion of the SA Air Force commander during the operation, Brigadier Dick Lord, was: Plan "never succeeded in regaining the offensive capability it had prior to Askari," he says. "Askari became the watershed in the course of the Angola/SWA war. Swapo Plan was reduced in military strength and from then onwards no longer posed a major threat." 72 And an independent observer like Francis Toase wrote in remarks published in 1985 that "the South Africans have successfully blunted Swapo's military edge. Indeed, the SADF has established a growing mastery over Swapo in the military sphere..." ${ }^{73}$ No wonder then, that Chester Crocker called Angola "the centrepiece of the SADF's anti-Swapo strategy". ${ }^{74}$

This fact was facilitated by the fact that the SADF successfully prevented Swapo from spreading the war so wide that the security forces could not adequately cover the entire operational area in Namibia intensively. According to Geldenhuys, the main purpose of the SADF's strategy "was to clean Kaokoland, Kavango and the Caprivi... If we could attain this goal, we could reduce the wide-spread insurgentinfested territory until only Ovambo remained. We could then concentrate our efforts there..."75

\footnotetext{
${ }^{71}$ Brown: "Diplomacy by Other Means", in Leys and Saul: Namibia's Liberation Struggle, p. 32 .

${ }^{72}$ Brigadier R.S. Lord: "Operation Askari (a Sub-commander's Retrospective View of the Operation)", Militaria, 22/4, 1992, p. 9.

${ }^{73}$ Toase: "The South African Army: The Campaign in South West Africa/Namibia since 1966”, in Beckett and Pimlott (eds.): Armed Forces \& Modern Counter-Insurgency, p. 216.

${ }^{74}$ Chester A. Crocker: High Noon in Southern Africa. Making Peace in a Rough Neighborhood (Johannesburg, Jonathan Ball, 1992), p. 57. His view on the Lusaka Accord appears on pp. 183-196.

${ }^{75}$ Geldenhuys: Dié wat wen, p. 68.
} 
Swapo's first geopolitical set-back was when President Kenneth Kaunda decided to kick the organisation out of his country in 1978. This was a breakthrough in that it made the insurgency in the eastern Caprivi impossible. "This was the beginning of the fulfillment of our plan", Geldenhuys commented. ${ }^{76}$ Infiltration into the eastern Caprivi became impossible.

Adding to Swapo's woes, Canu broke with its erstwhile ally in 1981, thereby dealing a death blow to the insurgency there. The fact that Swapo allowed Savimbi's Unita to become an ally of South Africa, now also came into play. As Unita dominated the whole southeast corner of Angola, this meant that any attempt to infiltrate into western Caprivi and Okavango became so fraught with danger as to be next to impossible. To the west, the Kaokoveld remained implacable to the Ovambodominated Swapo.

That left Ovamboland, admittedly Swapo's heartland and therefore a tough nut to crack. Nevertheless, the fact that this territory was only 56000 hectares big made it much easier for the security forces to keep it in an iron grip. Swapo also made sporadical attempts to infiltrate into the white farmlands south of Ovambo, but the bands were invariably hunted down and wiped out. "And so we reached our goal to limit the insurgency to Ovamboland in a relative short time", according to Geldenhuys. $^{77}$

That the war went rather well for the security forces is borne out by the South African statistics. If they are accepted as accurate, the casualty rate looked like this: ${ }^{78}$

Table 1:

\begin{tabular}{|l|c|c|c|}
\hline Year & Swapo losses & Sec. Forces losses & 'Kill ratio' \\
\hline $1966-{ }^{\prime} 74$ & 363 & 88 & $4,1: 1$ \\
\hline 1978 & 971 & 44 & $22,1: 1$ \\
\hline 1997 & 915 & 50 & $18,3: 1$ \\
\hline 1980 & 1447 & 100 & $14,5: 1$ \\
\hline 1981 & 1494 & 61 & $24,5: 1$ \\
\hline 1982 & 1280 & 77 & $16,6: 1$ \\
\hline 1983 & 913 & 96 & $9,5: 1$ \\
\hline 1984 & 916 & 39 & $23,5: 1$ \\
\hline
\end{tabular}

According to General Geldenhuys, the "kill ratio" on previously planned cross-border operations was 100:1, on general cross-border operations to dominate southern Angola 30:1 and within Namibia 10:1. ${ }^{79}$

\footnotetext{
${ }^{76}$ Ibid., p. 90.

${ }^{77}$ Ibid. Cf. also pp. 94-95 and 133; Steenkamp: SA's Border War, pp. 101, 107.

${ }^{78}$ Compiled from different sources.

${ }^{79}$ Geldenhuys: Dié wat wen, pp. 69-70.
} 


\section{Hearts and minds}

But a favourable "kill ratio" is not by a long chalk enough to win an insurgency war, as any American with combat experience in Vietnam will be able to tell you. In the end, destroying the enemy combat forces matters relatively little. Gaining and keeping the support of the local population is what really matters. Well, here the South Africans' success was a mixed one. In accordance with the SADF's COIN doctrine, the "hearts-and-minds" programme was started in 1974, albeit on a very modest scale. As the years went on, more resources were poured into a titanic battle for the Nambians' loyalty.

When Geldenhuys took over in 1976, Swapo was already spreading propaganda that the security forces were maltreating the local population in the operational area. The churches and international human rights organisations soon took up the matter, and a newspaper like The Namibian regularly published reports about murders, assaults, rapes and the like. ${ }^{80}$ It would, of course, be too easy although not entirely invalid - to try and diminish the impact of these allegations by pointing out that it was in Swapo's interest to spread such propaganda stories, whether they be true or not. This is, after all, the nature of politics. It would be very surprising indeed if Swapo did not exploit (and exaggerate) these stories for their propaganda value. But the most credible propaganda is based, even if only partly, on fact. And many stories about maltreatment, by and large, do have the ring of truth. Even a veteran South African paratroop officer like Brigadier-General McGill Alexander accepts, writing about the seventies, that "the counter-insurgency measures adopted by the SADF were, in the eyes of the local inhabitants, as closely akin to terrorism as anything done by Swapo". His nuanced and apparently carefully worded view is that "[i]ndividuals and groups of soldiers who ignored or deliberately flaunted instructions to treat people humanely exacerbated the situation, as in any war." 81

This does not mean that the SADF top echelon were not honest in their hearts-and-minds strategy. After all, they wanted to win the war, and their own doctrine dictated an approach wherein the locals would be won over. In the official Army Counterinsurgency Manual which was in force during the war, it was explicitly stated: "Unless the trust, confidence and respect of the people are won by

\footnotetext{
${ }^{80}$ Cf. for example Nujoma: Where Others Wavered, p. 321; Leonard: South Africa at War, pp. 69-72; Herbstein and Evenson: The Devils are among us, p. 105; Groth: Namibia: The Wall of Silence, pp. 28-31; Barbara König: Namibia. The Ravages of War (London, International Defence and Aid Fund for Southern Africa, 1983), pp. 46-47; Katjavivi: A History of Resistance in Namibia, p. 89. Examples of sworn statements by Namibians alleging to have been brutalised by the security forces are published in Heike Becker: "Narratives of War and Survival from Northern Namibia: The Liberation War in Postcolonial Namibian Writing", in Chris van der Merwe and Rolf Wolfswinkel: Telling Wounds. Narrative, Trauma \& Memory Working through the SA Armed Conflicts of the 20th Century (Stellenbosch, Van Schaik, 2002), pp. 201-208.

${ }^{81}$ Alexander: "The Raid on Cassinga", p. 34.
} 
the government and the military forces, the chance of success is greatly reduced. If the people support the government and the military forces, the enemy becomes isolated and cut off from its supplies, shelter and intelligence." 82

In fact, a considerable effort was already underway. Apart from troopies getting lectures about the locals and their ways as well as stern orders on how to treat the people, hundreds of conscripts were poured into the operational area as teachers, medics and doctors, builders, etc. Roads were built and tarred, hospitals, clinics and schools were built, bore-holes sunk, veterinary services provided, and so forth. $^{83}$

These efforts met with, at best, mixed results. In 1981 a British correspondent wrote in The Times that the SADF's civic action programme had some success in Kavango and the Caprivi, but that it was an "almost total failure" in Ovamboland. $^{84}$ General Geldenhuys also had a fairly nuanced view: The programmes "tended to prevent insurgency from starting in an area but were less successful in countering it if it had already commenced." 85 This is basically confirmed by Colonel Breytenbach, who points out that "most of the Ovambos in eastern Ovamboland, particularly the [majority clan of the] Kwanyamas, were firmly on Swapo's side. Satisfactory co-operation from the locals was rare and when it existed it had to be dealt with carefully. This changed to some extent when the Hearts and Minds campaign began to take effect, but we never fully weaned them from supporting Swapo." ${ }^{86}$ The election results of 1990 confirmed this analysis. (Of course, in the internal election of 1978, an event boycotted by Swapo, a countrywide voting percentage of 78 per cent was attained, ${ }^{87}$ but there is some doubt as to how free especially the Ovambos felt to vote or abstain as they wished.)

The South Africans were, of course, helped by the fact that they wisely never instituted the type of strategic hamlets or aldeamentos which were enforced at places in Vietnam, Rhodesia and the Portuguese colonies. ${ }^{88}$ No doubt the experience of concentration camps in the Anglo-Boer War, which were essentially the same thing, played a powerful role in the South Africans' decision.

${ }^{82}$ SA Army: "Counter Insurgency Manual", ch. 1.

${ }^{83}$ Geldenhuys: Dié wat wen, p. 68; Steenkamp: SA's Border War, p. 67.

${ }^{84}$ Steenkamp: SA's Border War, p. 97.

${ }^{85}$ Hamann: Days of the Generals, p. 74; Geldenhuys: Dié wat wen, p. 68.

${ }^{86}$ Breytenbach: The Buffalo Soldiers, p. 196. There is still a controversy about the role of Koevoet in this context. The SADF generals tended to view Koevoet, one of the tactically most succesful units in the security forces, as handling the locals very roughly and alienating them (cf. Hamann: Days of the Generals, pp. 65-66). On the other hand, Breytenbach (The Buffalo Soldiers, p. 192) and Peter Stiff (The Covert War, passim), are ardent defenders of the unit. Here too, as with the atrocity allegations, it is difficult to differentiate between propaganda and fact.

${ }^{87}$ Steenkamp: SA's Border War, p. 83.

${ }^{88}$ Heitman: South African Armed Forces, p. 192. 
One last remark about this subject. Following the example of the Chinese and Vietnamese, Swapo conducted its own campaign of selective terrorism. Local chiefs and black officials in service of the South African administration were, from time to time, murdered in order to impress on the people that Swapo would not tolerate traitors to the cause, and that it would be in their interests to support the movement. The most well-known cases were the murders of Ovambo "chief minister" Filemon Elifas and Herero chief and DTA chairman Clemens Kapuuo, but there were many others, as most chiefs tended to support South Africa. ${ }^{89}$ As usual, the ordinary people were the grass on which the elephants trampled while fighting each other.

Finally, a point Thomas X. Hammes stresses very much in his insightful study of revolutionary guerrilla warfare, is the fact that the revolutionaries should disperse their effort; they should not expend all on the military front, but utilise the entire spectrum of activities available to them. In their struggle, the South African ANC understood this very well. After visiting Vietnam in October 1978, they formulated a "four pillar strategy", being the mobilisation of the masses, the building of underground ANC structures within the country, the international isolation of the ruling class on all fronts (diplomatic, economic, cultural, sport, religious, etc.), and the armed struggle. Note that the last one constitutes only one of the four pillars.

Swapo dropped the ball on this. Although the movement did succeed in locking the Namibian Council of Churches "into an attitude not to question Swapo policy", 91 Lauren Dobell notes that the Swapo leadership concentrated on the "diplomatic route in its struggle to liberate Namibia", while the "organisation and mobilisation of popular resistance at home was neglected by the leadership in exile, as it pursued recognition by the international community of Swapo's status as the 'sole and authentic representative of the Namibian people' - in that order."92

\section{SWAPO starts losing the war}

Swapo was not a party to the 1984 Lusaka Agreement between South Africa and the MPLA government in Luanda, so it never considered itself bound by it. In fact, although Fapla, the MPLA's army, was bound by the treaty to cooperate with the SADF in preventing Swapo from moving south of the agreed line, it did so only very reluctantly and inefficiently. The result was that Swapo started moving

${ }^{89}$ Cf. Leys and Saul: "Introduction", in Leys and Saul: Namibia's Liberation Struggle, p. 15; Steenkamp: SA's Border War, pp. 74-75.

90 ANC: Armed Struggle and Umkhonto, Armed Struggle Complements People's Struggle, at www.anc.org.za/ancdocs/history/mk/forward.html.

${ }^{91}$ Philip Steenkamp: "The Churches", in Leys and Saul: Namibia's Liberation Struggle, p. 107. To their everlasting shame, the Namibian Council of Churches, according to Steenkamp, "acted as an instrument of domination rather than of liberation". Cf. ibid., p. 111.

${ }^{92}$ Dobell: Swapo's Struggle for Namibia, p. 20. 
southwards and infiltrating Ovamboland again within a short time, and after six months or so the insurgency was again in full swing. ${ }^{93}$

But the military realities did not change. The guerrillas still had to walk hundreds of kilometres to the border, burdened with all the necessities for guerrilla warfare. South of the border, Koevoet, $101 \mathrm{Bn}$ and the rest of the SADF and SWATF units were still waiting for the guerrillas and hunted them down mercilessly. An attempt or two to activate Kavango and the Kaokoveld failed miserably; the insurgency remained firmly limited to Ovamboland. And even there, the locals gave ever more intelligence to the security forces. In a press interview, the new GOC South West Africa of the SADF and SWATF, Major-General Georg Meiring, gave telling statistics. In 1983, he said, 64 per cent of the population gave information about Swapo movements to the security forces. In 1984 this was almost 317 per cent (which, of course, meant that one person gave several pieces of information) and in 1986 almost 600 per cent. An insurgent was on average only six days in Ovambo before intelligence about his whereabouts and movements reached the security forces. ${ }^{94}$

So the carnage went on, and the number of Swapo guerrillas being able to survive while moving around and politicising the local population dwindled. That they kept on coming, it must be said, is a tribute to their courage and steadfastness in the face of daunting odds. Swapo's capabilities were further hamstrung by the fact that the MPLA exacted a heavy price for its hospitality. Swapo was forced to furnish two infantry brigades for the war against Unita. According to military intelligence, in January 1985 Swapo had about 8500 trained fighters at its disposal. Of these, 3 400 were fighting against Unita, 1200 were employed in administration and logistics, 1200 garrisoned the base camps and headquarters, and 600 were headquarters staff. This left only 1500 available for the war in Namibia. Two years later, the numbers looked even worse: out of a total of 8350 men, 2700 were combating Unita, 2700 were in base garrisons (remember that the SADF could attack them at any moment!), 1050 were headquarters personnel, another 500 were defending temporary bases in southern Angola, and only 1000 were available for infiltration into Namibia. ${ }^{95}$

Table 2:

\begin{tabular}{|l|c|c|c|}
\hline Year $^{96}$ & Swapo losses & Sec. forces losses & 'Kill ratio' \\
\hline 1985 & 590 & $?$ & $?$ \\
\hline 1986 & 645 & 33 & $19,5: 1$ \\
\hline 1987 & 747 & 72 & $10,4: 1$ \\
\hline Total $^{97}$ & 11291 & 715 & $15,8: 1$ \\
\hline
\end{tabular}

\footnotetext{
${ }^{93}$ Hamann: Days of the Generals, p. 78.

${ }^{94}$ Steenkamp: SA's Border War, p. 145.

${ }^{95}$ Heitman: South African Armed Forces, pp. 174, 176. Cf. also Steenkamp: SA's Border War, p. 133.

${ }^{96}$ Compiled from different sources.
} 
The absolute figures are down, compared to the years before 1985. But take into account that the SADF's role in Angola was changing. Increasingly Fapla and the Cubans became the target instead of Swapo.

These SADF operations in aid of Unita, which culminated in Operations Modular, Hooper and Packer in 1987-'88, cannot, of course, be the subject of this study. Suffice it to say that South Africa could not afford to lose Unita as a strategic partner, as the Angolan rebel movement occupied the southeastern part of the country, thereby in effect denying Swapo access to Okavango and the western Caprivi. This was an important factor in limiting the insurgency to Ovambo, one of the SADF's prime strategic goals. ${ }^{98}$

Apart from the rough handling Swapo insurgents received from the security forces on the battlefield, the movement's internal cohesion also started to sag in the eighties, partly because of the military difficulties, but also because of the capricious and dictatorial leadership of Sam Nujoma. "The history of Swapo in exile," writes Pastor Groth, "was riddled with internal crises. Throughout the sixties, seventies and eighties, the liberation movement lurched from one conflict to another, with a continually escalating trend towards violence among the leadership." He quotes an anonymous Namibian church leader in early 1979: "The same process has started in Swapo which has also happened in Russia under Stalin... I am extremely concerned that there will be an era of Stalinism for Swapo in exile." 99

This prophecy came to fruition in 1985 , when the so-called spy scare broke out. ${ }^{100}$ About 2000 Swapo members were detained, mostly in Angola, but also in Zambia, under suspicion of being South African spies. Hundreds of Swapo members were ordered to halls in Lusaka, London, Paris, Bonn and under places, where those present "watched a number of videos they would never forget as long as they lived," according to Pastor Groth.

This was the first time they saw the faces of the so-called spies - the wellknown faces of friends who had fought alongside them for many years, people who had been loyal, reliable Swapo members both at home and abroad. They were now confessing their guilt, giving precise details of their lives in Namibia and in exile, their families and how they supposedly became enemy agents. The more the audience saw their faces and heard their voices, the more they were seized by paralysing horror. As part of their confessions, the 'spies' gave the names of other freedom fighters who were also under

\footnotetext{
${ }^{97}$ On 1.11.1988.

${ }^{98}$ Cf. Scholtz: “Cuito Cuanavale: Wie het werklik gewen?", Scientia Militaria, 28/1, 1998, pp. $16-61$.

${ }^{99}$ Groth: Namibia: The Wall of Silence, pp. 100, 101-102.

${ }^{100}$ It is important to note that the ANC at the same time and roughly the same vicinity had a similar experience. It remains to be investigated whether there was a causal relationship between the two.
} 
suspicion of espionage. That evening, the unsuspecting audience suddenly began to fear for their own lives as they heard their own names being mentioned and realized that they too, were branded as spies and traitors. They knew that this would lead to imprisonment and torture. ${ }^{101}$

And it did. Hundreds were incarcerated, assaulted, maltreated, raped, tortured; some died. And no-one was given a fair hearing. As Philip Steenkamp succinctly puts it, "subsequent evidence makes in clear that the overwhelming majority were not spies, but simply critics of the leadership, or just people believed liable to be such critics." 102

However gruesome these events, the question that must interest us here most, is how this affected Swapo's military capabilities. It is true that many Swapo guerrillas bravely went on fighting, trying to infiltrate Namibia, even though they must have known that their chances of success could not have been great. But the brutal suppression of all real or even imagined independent thought surely must have dampened their enthusiasm, if not for Namibian independence, then for Swapo, and lowered their morale. The power of the Security Department, like that of the KGB in the USSR or the Gestapo in Nazi Germany, was all-encompassing. The Canadian researchers Colin Leys and John S. Saul - who are, ironically, sharply critical of the apartheid government and its war effort in Namibia - (they have, arguably, done the most research into Swapo's struggle past) write about "the growing Stalinist influence from 1976 onwards". They come to the conclusion that "after 1976 all questioning of policy decisions was delegitimised, so that not even leaders as senior as Hage Geingob (later to become Namibia's first Prime Minister) or Lucas Pohamba could get a discussion in the central Committee of what the security organisation was doing." In the end, they say, "one [anonymous] senior cabinet minister acknowledged to us, "there was fear everywhere. The Central Commitee could not act. We were saved by [the implementation of Security Council Resolution] 435."103

This last sentence is important, and is further buttressed by Leys' and Saul's assertion that "Swapo had all but paralysed itself - for despite its many strengths and its subsequent electoral success, this is hardly too strong a summary of its condition on the eve of the 'peace agreement' that brought Swapo home and into office after April 1989." 104

It is true that Swapo gave a last military convulsion when it sent 1600 insurgents across the border on 1 April 1989, the day on which the implementation

\footnotetext{
${ }^{101}$ Groth: Namibia: The Wall of Silence, p. 105.

${ }^{102}$ Steenkamp: "The Churches", in Leys and Saul: Namibia's Liberation Struggle, p. 106. For testimonies about the maltreatment of prisoners, cf. Groth: Namibia: The Wall of Silence, pp. 114-129.

${ }^{103}$ Leys and Saul: "Liberation without Democracy?", Journal of Southern African Studies, 20/1, March 1994, p. 145.

${ }^{104}$ Ibid.
} 
of the peace accords were supposed to have started. But it was a miserable failure. The breach of the accords was so blatant that South Africa reactivated Koevoet and $101 \mathrm{Bn}$ - with the concurrence of the UN and the international community - and wiped the insurgents out. Altogether 312 of them and 25 of the security forces died unnecessarily in this final death dance, which changed nothing. It was a monumental miscalculation by the Swapo leadership. ${ }^{105}$

\section{Conclusion}

This is not the place to recount the final peace negotiations which culminated in the New York accords of 22 December 1988. Suffice it to say that the international political climate which had made the perpetuation of the war in Namibia thus far possible, was starting to change. In 1985 President Mikhail Gorbachev took over power in the Kremlin. He quickly became aware of the fact that the communist system was hugely inefficient and that the USSR could not sustain the economic burden of the Cold War much longer. This meant, inter alia, that the Soviet Union started scaling down its financial and military aid for proxy wars in the Third World, such as Angola and Namibia. On the one hand, this reduced the practical and ideological backing available to the MPLA, Swapo and the ANC, but on the other took away the South African government's only claim to be fighting a respectable war, namely its opposition to communism. At the same time, the clashes between Angola, Cuba and South Africa in 1987-'88 meant that both protagonists had a good look down the precipice of total war - and didn't like what they saw.

The New York accords, therefore, were a compromise al three could live with. It stipulated that South Africa would pull out of Namibia, that UN-supervised elections would take place, and that the territory would finally become independent. At the same time, all Cuban troops would leave Angola. Apart from Swapo's blunder of 1 April 1989, all went well. The elections were duly held, and Swapo received 57 per cent of the votes. Sam Nujoma was inaugurated as first president of the newly independent Namibia.

So, who won the war? As far as South Africa is concerned, it can rightly be stated that it did well in terms of its military strategy and tactics. Almost every firefight between the security forces and Swapo ended in a victory for the former. After Ongulumbashe, Swapo never succeeded in establishing a single base on Namibian soil. There were no liberated areas where its forces could recuperate and set up an alternative government. The bases in neighbouring Angola were pushed back hundreds of kilometres, and the cadres had to brave a broad strip of land intensely dominated by the SADF before entering Namibia. And there they were chased, pursued and hunted down mercilessly by professional experts, often natives from the north itself. The casualty figures tell a story of Swapo - at least after the

${ }^{105}$ Stiff: The Covert War, p. 465. 
South African countermeasures got under way in the late seventies - getting beaten fair and square.

Swapo failed in spreading the war wide. Their attempts to activate Caprivi, Kavango and the Kaokoveld after the early seventies - let alone the rest of the country - bore no fruit. On the contrary, the SADF's avowed goal to limit the insurgency to Ovamboland was a resounding success.

After having had the initiative until about 1978-'79, Swapo progressively lost it. The South African invasions of Angola were, perhaps, the single most important factor in causing Swapo to lose the initiative. It is as the legendary Vietnamese General Vo Nguyan Giap, mastermind of the French and American defeats in Vietnam, said in an interview in the nineties: "We had to force the enemy to fight the way we wanted them to fight. We had to force the enemy to fight on unfamiliar territory." "106 In Vietnam the guerrillas succeeded. In Namibia the South African-led COIN forces did. The final debacle of April 1989 merely served to underline Swapo's military defeat. It may safely be said that, had international developments not intervened, the long awaited coup de grace may not have been far off.

And yet, there is an interesting story which illustrates the point. When visiting Hanoi in 1975 just after the Vietnam War, the American strategist Colonel Harry Summers told his North Vietnamese counterpart: "You know you never defeated us on the battlefield." The other colonel thought for a moment, then answered: "That may be so, but it is also irrelevant.",107

The North Vietnamese officer, of course, exaggerated. The military side of things in a revolutionary guerrilla war is not completely irrelevant. But, as the SADF doctrine had it, its weight was about 20 per cent compared to the 80 per cent pulled by politics, socio-economic factors, psychology, etc. Winning every firefight, succeeding brilliantly in almost all your strategic goals, is simply not enough. In the end you have to win over the hearts and minds of the people. The South Africans did rather well here, too, but only in the less important areas of Caprivi, Okavango and Kaokoveld. Ovamboland, accommodating 46 per cent of the population, proved to the centre of gravity. And, although the SADF's civic action programmes did have some effect, in the end the Ovambos still voted for Swapo and helped it to a convincing majority. The fact that Swapo, at least for the time being, did not get a two-thirds majority, mattered little. Sam Nujoma occupied the Namibian presidency. South Africa failed in its bid to prevent Swapo getting into power.

106 "Interview with Vo Nguyen Giap, Viet Minh Commander", at www.pbs.org/wgbh/peoplescentury/episodes/guerrillawars/giaptranscript.html.

107 Harry G. Summers, jr: On Strategy: The Vietnam War in Context (Pennsylvania, Strategic Studies Institute, US Army War College, n.d. [1982]), p. 1. 
This makes it sound as if Swapo actually won. And yet that is not true either. Swapo's strategic goal was not simply to occupy the seats of government. It wanted unfettered power. It wanted a one-party dictatorship without having to take a pesky parliamentary opposition into account. It failed in this bid. As John Turner puts it: "Although the political settlement permitted Swapo to win and control the new government of independent Namibia, it was only after a free and fair election of the sort it would never have agreed in the heyday of the Cold War. Swapo was ultimately cornered by its lack of success as an insurgent organisation into accepting the results of a democratic alection to determine the fate of Namibia."108

So, once again, who won? Truth is, nobody - and everybody. Nobody received a knockout blow. Neither did any of the parties have the privilege of their arm being held aloft by the referee before an extatic crowd. But the fact that Namibia has a liberal democratic constitution and that anyone can vote for an opposition party and criticise the government, is, perhaps, as near to a victory for the people as can be imagined.

${ }^{108}$ Turner: Continent Ablaze, p. 34 